\title{
Kernos
}

Revue internationale et pluridisciplinaire de religion grecque antique

$23 \mid 2010$

Varia

\section{The Molpoi Inscription: Ritual Prescription or Riddle?}

\section{Angelos Chaniotis}

\section{(2) OpenEdition \\ Journals}

Electronic version

URL: http://journals.openedition.org/kernos/1594

DOI: 10.4000/kernos.1594

ISSN: 2034-7871

\section{Publisher}

Centre international d'étude de la religion grecque antique

Printed version

Date of publication: 1 January 2010

Number of pages: $375-379$

ISSN: 0776-3824

\section{Electronic reference}

Angelos Chaniotis, «The Molpoi Inscription: Ritual Prescription or Riddle? », Kernos [Online], 23 | 2010,

Online since 15 September 2011, connection on 21 September 2020. URL : http://

journals.openedition.org/kernos/1594; DOI : https://doi.org/10.4000/kernos.1594

This text was automatically generated on 21 September 2020 .

Kernos 


\title{
The Molpoi Inscription: Ritual Prescription or Riddle?*
}

\author{
Angelos Chaniotis
}

\section{REFERENCES}

Alexander HERDA, Der Apollon-Delphinios-Kult in Milet und die Neujahrsprozession nach

Didyma. Ein neuer Kommentar der sog. Molpoi-Satzung, Mainz, Philipp von Zabern, 2006.

1 vol. 22,5 × 30,5 cm, 543 p., 22 pl. (Milesische Forschungen, 4). ISBN : 3-8053-3560-1.

1 Greek ritual regulations are notoriously elliptical. Witness, for example, the 21stcentury worshippers of the Hellenic gods who face great difficulties in their attempts to revive pagan rituals. Greece's neo-pagans made their most spectacular appearance in August 2008, when they ascended the Acropolis to protest against the transportation of ancient votive objects from the old to the new Acropolis Museum. ${ }^{1}$ Dressed in white garments and crowned with wreaths, they raised their hands in prayer, performed libations, and recited ancient hymns to propitiate the gods against what they regarded as an act of sacrilege. Even if the pagan gods did exist - an unresolved question since the time of the ithyphallic hymn for Demetrios Poliorketes - I very much doubt that this ritual would have succeeded. We simply do not know enough details about the rituals of propitiation, or about any other rituals for that matter, to be able to perform them. Although it is often claimed that we know how a 'normative' Greek sacrifice was performed, I belong to the skeptics. With very few exceptions (especially detailed magical prescriptions) Greek cult regulations are like the recipes of Apicius; they provide some of the ingredients but not all of the information needed to make a ritual work or make the food taste tolerable. Normative ritual texts presuppose knowledge which they do not provide. ${ }^{2}$ For this reason, historians of religion are fascinated with the few detailed cult regulations that do exist, such as the purification rituals of Selinous ${ }^{3}$ and the rites of the Milesian board of religious singers, the molpoi. ${ }^{4}$ But as the large number of studies on these texts show, even in the case of detailed cult regulations no consensus can be reached regarding many (most?) questions. However, 
this by no means renders new approaches futile, especially when they are based not only on the analysis of one single text but draw upon many parallels. This is certainly the case with Alexander Herda's book on the cult regulations of the moploi, a work of great erudition and acumen whose arguments are, at times, highly convincing.

2 A short review cannot do justice to a book of more than 550 pages and 3,000 footnotes, even if the book is dedicated to a single inscription of 45 lines. The cult regulation of the molpoi in Miletos is of singular importance for the study of Greek religion, Greek leges sacrae, and the history of Miletos. It has been studied many times, challenging the interpretative skills of such great scholars as Wilamowitz. What makes this text so important is the fact that it is one of the most detailed Greek cult regulations which touches upon an array of ritual matters (procession, sacrifice, performance of ritual songs). But it is also a late copy of an earlier text which underwent several revisions; the meaning of many of its terms is unknown; and the syncopated mode of expression makes many of the ritual prescriptions puzzling.

Herda's book is based on a PhD dissertation at the Freie Universität in Berlin. The text is presented in a critical edition with German translation in the first chapter (p. 9-14). In this translation the author adds many words not in the Greek in order to make clear how he understands the text; these additions are clearly marked as such, but for reasons that I shall explain below this translation cannot be used uncritically. Two short chapters treat the chronological problems (p. 15-20) and the discovery and original setting of the inscription (p. 21-30). The largest part of the book is a very detailed line-by-line commentary of the text (p. 31-424). For this commentary Herda has exploited information contained in hundreds of inscriptions and literary sources as well as in the archaeological remains in Miletos and Didyma pertaining to a large range of subjects, from rituals (oath, procession, sacrifice, ritual song and dance, rites of maturation), cult associations, and the cult of Apollo to political institutions and the history of Miletos. The commentary is followed by a summary (p. 425-442) and an overview of the contents of this regulation (p. 443-446). Four short chapters dedicated to the relationship between Miletos and Didyma (p. 447-456), desiderata of future research (p. 457-462), the parts of the sacrificial animals (p. 463-468), and victims mentioned in cult regulations of Miletos and Didyma (p. 468-471), detailed indices, and numerous figures complete this book.

Herda's book is not an easy read, not only because of its size and weight (and the glittering paper). Although the analysis is clearly divided into small chapters with lucid headings, the argument is very complex and often circular. It is best to begin with the conclusions in order to establish what Herda intends to prove, and then return to the commentary and decide for oneself whether the evidence he provides supports these claims. Herda's commentary presents a 'Gesamtinterpretation' of this inscription, an interpretation according to which every section of the cult regulation is an integral part of a single ritual complex. I shall now summarize the main points.

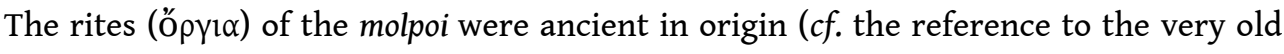
gylloi), going back at least to the eighth century BCE. They were first written down in the late Archaic period (c. 540 or $525 \mathrm{BCE}$ ), but the text underwent several revisions before the late Hellenistic period (c. $200 \mathrm{BCE}$ ) when the inscription that we have today was made. This inscription was set up in connection with the upgrading of the Didymeia festival, which Herda identifies with the $\pi \alpha v \theta$ v́ $\alpha$ ('das Jahr des Allopfers'). The largest part of the inscription treats rituals of the festival of Apollo which started 
on his sacred day (the 7th of Taureon) and continued to the 10th of the month (lines 6-18 and 23-25). This festival - and this is Herda's main contention - was the new year's festival in Miletos. On the 7th Taureon the new aisymnetes was inaugurated in his office and sacrifices. On the 8th the aisymnetes swore in the new proshetairoi, representatives of the tribes. On the 9th the aisymnetes performed sacrifices together with his retiring predecessor. Hence, the most important officials in this festival were the two

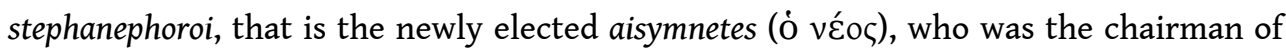
the cult association of the molpoi, and his retiring predecessor ( $\dot{\varepsilon} \dot{\varepsilon} \xi \omega \dot{v}$ ). The stephanephoros, a synonym for aisymnetes, and the proshetairoi, representatives of the tribes, formed together the board of the prytaneis, the seat of which was a building in the Delphinion, designated as to molpon, which also served as the prytaneion of Miletos; here the civic hearth was located. This is where the rituals took place. In connection with this festival, the young men of Miletos completed their 'initiation cycle' and were accepted into the citizen-body, performing choral contests. The contests ( $\dot{\alpha} \mu \imath \lambda \lambda \eta \tau \eta ́ p ı \alpha)$ were a nocturnal celebration followed by a banquet. After these rites for Apollo Delphinios a procession from Miletos to the sanctuary of Apollo in Didyma took place on the 10th Taureon (lines 18-20 and 25-31); this takes up the largest part of the text (and of Herda's commentary; p. 167-385). All this constituted a 'new-year's festive cycle' ('ein rituell gefaßter Neujahrszyklus') comparable to the Panathenaic festival in Athens. Other main participants in the celebrations included the young men (oi véol) and the Onitadai, a clan of ritual specialists originating in a legendary ancestor.

There is no doubt that this is a very original interpretation. But is it also convincing? It certainly did not convince me, primarily because there is nothing in the text that directly and unequivocally confirms Herda's assumptions. If he is right, then the Milesian molpoi made sure that no one except them would understand that their text refers to a new-year's festival, since they do not use the Greek term for a new-year's

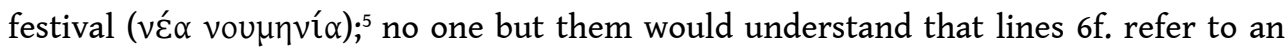
oath ceremony, during which the newly elected aisymnetes swore in five new proshetairoi, because no Greek word related to an oath ceremony is used; only they would understand that the same word (neos) is used within a few lines in two different meanings: 'young man' (line 16) and 'new magistrate' (line 10). Yes, cult regulations are elliptical and presuppose a certain amount of knowledge, but at least they make clear which matter they treat. None of the main matters which Herda assumes to be the subject of this text is immediately apparent. If the molpoi took the trouble to write down their orgia, I think that they did so in order to provide answers to those who were to perform them in the future, not in order to confront them with riddles. But I may be wrong.

7 The main problem with Herda's interpretation is precisely that it is a 'Gesamtinterpretation', an interpretative construct, into which the interpretation of every single detail is supposed to be integrated. But by insisting on this, Herda has jeopardised his construct and shifted his reader's interest from the excellent commentary on the procession from Miletos to Didyma (nearly half of the book) towards a very speculative issue. The problem with 'Gesamtinterpretationen' is that if the interpretation of the single details proves to be unfounded, unlikely, or even wrong, then the whole edifice collapses. As far as I can see, far too many points of detail are not supported by unequivocal evidence, for some others the probability is limited, and some views are evidently wrong. In the following section I shall unavoidably focus 
on only four points of criticism - to present more would require a small monograph. These weak points are not at all representative of Herda's usually careful and insightful analysis - especially as regards the reconstruction of the procession - but I think that they reveal the weak foundation of the interpretative construction.

8 First, I find it very unlikely that in Miletos the new year did not begin on the first day of a month, as is the usual practice in the Greek world and as the Greek term for 'new

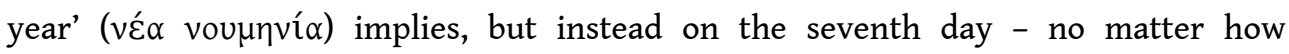
important the 7th day is for the city god Apollo.

9 Secondly, the idea that the term stephanephoroi refers to the old and the new aisymnetes, a view which Herda himself regards of seminal importance for his interpretation (p. 428: 'ein wesentlicher Schlüssel zum Verständnis'), seems to me contradicted by lines

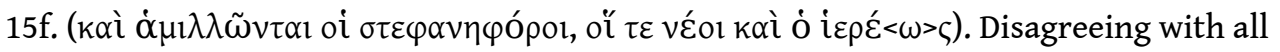

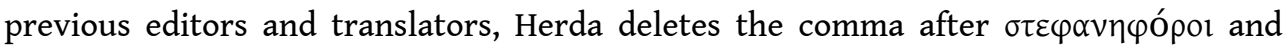
translates: 'und die Stephanephoroi, die Neoi (Jungbürger) und der Priester führen den Wettkampf'. According to Herda $\dot{\alpha} \mu \imath \lambda \lambda \tilde{\omega} \nu \tau \alpha$ l has three subjects. This is evidently wrong. Only if $\tau \varepsilon$ had been used together with the first subject (i.e., $\dot{\alpha} \mu \imath \lambda \lambda \tilde{\omega} \nu \tau \alpha$ ol $\tau \varepsilon$

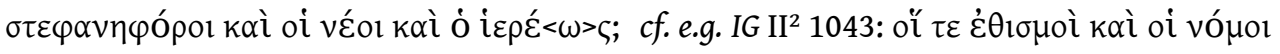

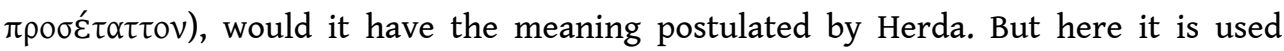

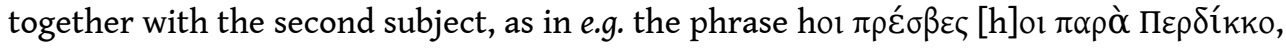

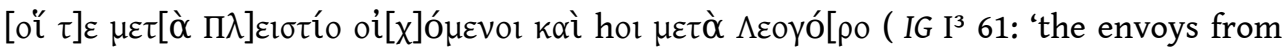
Perdikkas, both those that came with Pleistias and those that came with Leagoras', not 'the envoys from Perdikkas and the envoys that came with Pleistias, and those that

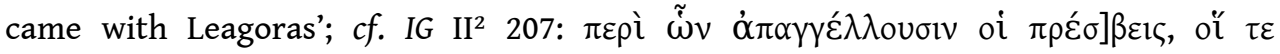

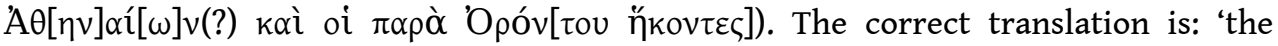
'crown-bearers' perform a contest, both the new ones and the priest'. Consequently, Herda's assumptions about the stephanephoroi and their relation to the aisymnetes (the old and the new) lack any foundation. Who were the neoi? This attribute, according to my interpretation, can only refer to stephanephoroi, to 'crown-bearers', designating a particular sub-group within those citizens who on the day of the festival wore wreaths. It is quite possible that they were young men, but not necessarily the young men of Miletos, i.e. the entire age-class of young men.

Thirdly, looking for parallels for the inauguration of the new magistrates in connection with the festival of the divine patron of a city, Herda adduces the decree of Magnesia on the Maeander concerning the festival Isiteria. However, the relevant passages are completely misunderstood. Herda claims (p. 61) that the festival's name means 'Antrittfest'; on that day (6th Artemision) the old and the new stephanephoros and the old and new priestess of Artemis perform the procession and the sacrifice of the Isiteria. All this is evidently wrong. The problem is not that in this period 'Antrittsfest' in Greek

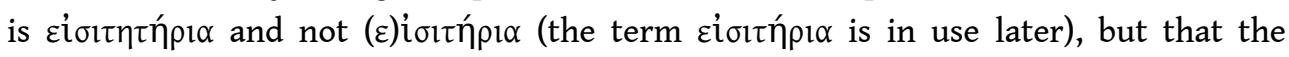
festival in Magnesia derives its name from the fact that it was established to commemorate the inauguration of Artemis' new statue. This is not my claim but the

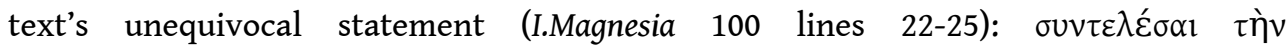

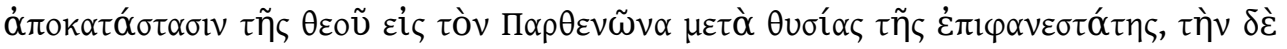

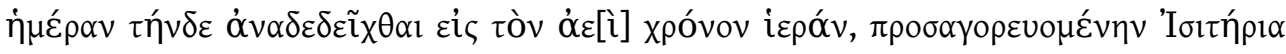
('the return of the goddess in the Parthenon shall take place accompanied by a most stunning sacrifice and this day shall be declared a sacred day for all time and it should be called Isiteria'). Herda's assumption that the old and new priestess and the old and 
new stephanephoros officiated together during this festival, which represents Magnesia's new-year festival, is based on a complete misinterpretation of the text. The text reads

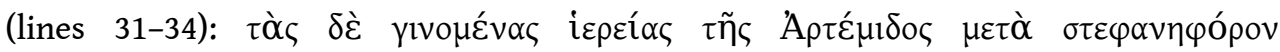

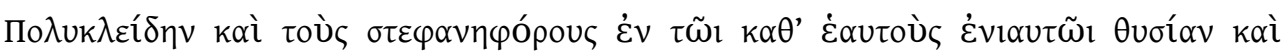

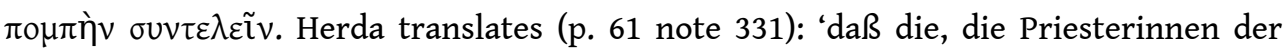
Artemis sind, zusammen mit dem Stephanephoros Polykleides das Opfer und die Poma ausrichten und [ebenso] die Stephanephoroi, ein jeder in seinem Jahr'. But the text has

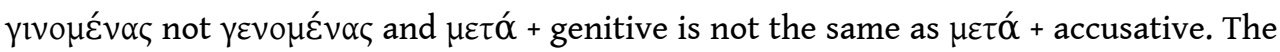
correct translation is: 'the women who shall become priestesses of Artemis after (the year of) the stephanephoros Polykleides and the stephanephoroi shall celebrate the sacrifice and the procession in their respective years of service'. The text simply prescribes what should happen in the future; it does not prescribe joint sacrifices by the old and new office-holders. Consequently, it cannot support Herda's interpretation of the Milesian inscription.

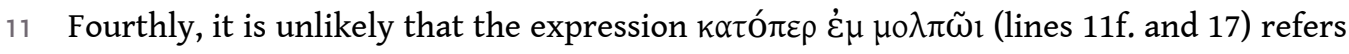
to a building. It gives instruction that wine should be mixed in the same manner 'as happens in the house of the molpoi' (and not as one would spontaneously understand:

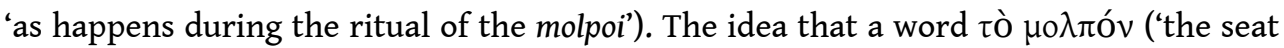
of the molpoi) developed from $\tau$ ò $\mu \circ \lambda \pi \varepsilon \tilde{o}$ ov defies the rules of Greek phonology. The

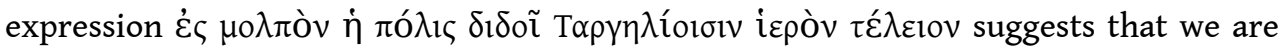
dealing with a rite ('during the Thargelia the city gives a full-grown sacrificial animal for the performance of the molpos) rather than with a building - buildings do not receive sacrificial animals, and a particular building requires the definite article.

12 As already said, to critically discuss all of Herda's argument would require a small monograph. I have only presented a very small selection of the weak points which leave me unconvinced as to the validity of his 'Gesamtinterpretation'. I have not listed the many cases in which I cannot find any supporting evidence for an assumption, for instance for the view that the Milesian prytaneis were the aisymnetes and the proshetairoi, for the identification of the prytaneion with the house of the molpoi, for the nocturnal character of the contests, for the beginning of the procession to Didyma on 10th Taureon and so on. I repeat that my selection of weak points is not representative of the whole work. In innumerable cases Herda's comments are insightful and valuable.

It is not easy to present an appraisal of this book. The reconstruction of the procession from Miletos to Didyma, in my view the best part of the book, reveals Herda's excellent knowledge of the topography, archaeology, and written sources. His reconstruction of the history of the monument is a nice example of painstaking microscopic work. The discussion of the significance of the cult of Apollo for Milesian identity is excellent and represents an important contribution to the study of religion as an aspect of identity in Greek poleis. The analysis of the function of the Onitadai in Milesian sacrificial ritual is very original and for the most part convincing. Although I am not convinced that this text has anything to do with a new-year festival - or with one single festival (the text also contains regulations concerning the Thargelia and the Metageitnia), Herda has correctly stressed the neglected significance of new-year festivals not only for the political life of the Greeks (inauguration of magistrates) but also for society and religion. ${ }^{6}$ His studies of banquets, choral performances and processions are well founded, exploiting an abundance of sources. Scholars working on the history of Greek religion (preferably not undergraduate students) will use Herda's book with great gain, 
especially regarding the topography of Miletos and the reconstruction of one of the best known processions in an ancient city. That some of them - like the author of this review - may remain unconvinced that all this happened on the Milesian new-year festival and that the officials, who are mentioned in this text, had the function attributed to them by the author, does not diminish the value of this study. If some of the riddles of the molpoi inscription remain unsolved, it is not because the inscription itself was meant to be a riddle.

\section{NOTES}

*. Review of Alexander HERDA, Der Apollon-Delphinios-Kult in Milet und die Neujahrsprozession nach Didyma. Ein neuer Kommentar der sog. Molpoi-Satzung, Mainz, Philipp von Zabern, 2006. 1 vol. 22,5 × 30,5 cm, 543 p., 22 pl. (Milesische Forschungen, 4). ISBN : 3-8053-3560-1.

1. http://www.architectsjournal.co.uk/news/pagans-enlist-gods-in-protest-against-bernardtschumis-new-acropolis-museum/1819069.article (accessed on 16 August 2009).

2. See my remarks in "The Dynamics of Ritual Norms in Greek Cult", in P. BRULÉ (ed.), La norme en matière religieuse en Grèce antique, Liège, 2009 (Kernos, Suppl. 21), p. 91-105.

3. NGSL 27.

4. LSAM 50; Milet VI 1, 133.

5. SEG XXI 510, line 2; XXXII 1243, line 31; I.Cret. I ix, 1, lines 146f. See R.J. ноDот, "Décret de Kymè en l'honneur du prytane Kléanax", Paul Getty Museum Journal 10 (1980), p. $175 f$.

6. Cf. my analysis of the connection of new-year festival in Teos with the cult of Antiochos III and the ephebeia: "Isotheoi timai : la divinité mortelle d'Antiochos III à Téos", Kernos 20 (2007), p. 162-164.

\section{AUTHORS}

\section{ANGELOS CHANIOTIS}

School of Historical Studies

Institute for Advanced Study

Einstein Drive

Princeton, NJ 08540

achaniotis@ias.edu 